\title{
An Overview of HIV on World AIDS Day: A Short Commentary
}

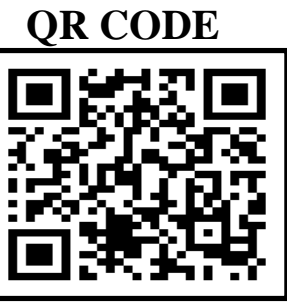

MANISHA SINGH

Acquired immunodeficiency syndrome (AIDS) is caused by Human immunodeficiency virus (HIV). HIV infections cause a gradual decrease in $\mathrm{CD}_{4}+$ cells and these cells are an indicator of the immune system including the body's natural defence system against pathogens and illness. ${ }^{1}$ AIDS is defined as the advanced stage of HIV infection with $\mathrm{CD}_{4}$ cell count less than $200 / \mathrm{mm}^{3}$. AIDS is characterized by immunosuppression which can result in several opportunistic infections, tumors, and cancers.

The World Health Organization (WHO) and UNAIDS in 2019 estimated that globally 38 million people were living with HIV, with 1.7 million people newly infected with HIV. WHO also estimated that approximately 6,90,00o people died due to AIDS related illness. ${ }^{2}$ According to National AIDS Control Organization (NACO), Ministry of Health and Family Welfare in 2019 estimated 23.49 lakh people living with HIV, with 69.22 thousand people newly infected with HIV. They also estimated 58.96 thousand AIDS related deaths in 2019. ${ }^{3}$

The purpose of World AIDS Day is to educate people about the transmission of HIV. The spread of infection is mostly through sexual contact, infected mother to her baby and blood transfusion. Understanding the success of different approaches for prevention of HIV infection and its treatment is also important. This day is celebrated to give a tribute to the people living with HIV and to the people who sacrificed their life due to this deadly disease. Clinical testing should be done for every individual who are at risk of HIV infection.

Diagnosis of AIDS is presence of HIV infection. The investigation of HIV is done by viral culture, ELISA, Western Blot, and PCR. The patient with positive HIV infection should be started with Antiretroviral treatment to decrease the severity of the infection. The viral load should be checked for patients on ART to know that any treatment modification is required, or the patient is responding well to the treatment.

Covid 19 has enrolled the entire country with its negative impact on society. HIV remains an important risk factor of Covid 19 infection and there is an increased mortality of HIV infected patients due to Covid 19 infection. ${ }^{4}$ People with low $\mathrm{CD}_{4}$ cell counts are at a higher risk of Covid 19 infection. ${ }^{5}$ These immunosuppressed patients should be tested for Covid 19 infection and adequate observation, and monitoring should be done to prevent further complications. They should be prioritized to receive vaccination when compared with individuals with no HIV infection.

HIV patients have oral manifestations such as fungal infections, viral infections, bacterial infections, HIVassociated malignancies, and other lesions including sialadenitis and aphthous ulcers. ${ }^{1}$ Recent study on the oral manifestations of Covid 19 patients reported taste and smell alterations, xerostomia, aphthous-like lesions, herpetiform/zosteriform lesions, and salivary gland disease. ${ }^{6}$ Another study included mucositis, candidiasis, HSV-1 (Herpes simplex virus) infections as symptom of Covid 19 infection. ${ }^{7}$ Further studies should be carried in India to assess HIV patients with oral symptoms of covid 19 infection to improve the quality of life of HIV patients.

People should be advised on safer sex using condoms and to avoid sharing of injections to prevent transmitting HIV to uninfected people. It is important to prevent transmission of virus from mother to child during pregnancy and delivery. Pre exposure prophylaxis medicine is required for people who have regular exposure to HIV patients by choice or profession. Post exposure prophylaxis medication is required when the exposure of HIV is immediate and should always be given within 72 hours.

(C) Manisha Singh. This is an open access article distributed under the terms of the Creative Commons Attribution License CC-BY-NC 4.0, which permits unrestricted use, distribution and reproduction in any medium, provided the use is not commercial and the original author(s) and source are cited. Submitted on: 01-Dec-2021; Accepted on: 18-Dec-2021 


\section{CONCLUSION}

This short commentary will help in decreasing the HIV infection and its progression to AIDS. Changing the attitude and behaviour of people toward this epidemic is important to decrease the spread of infection. Testing should be advised with the start of Antiretroviral drugs once the patient is positive for HIV infection. Funding resources to the organisations working for HIV patients will improve the health status of these patients.

\section{REFERENCES}

1. Kim SM, Lee JH. Importance of various oral manifestations regardless of $\mathrm{CD}_{4}$ cell count in HIV/AIDS patients. J Korean Assoc Oral Maxillofac Surg. 2018; 44:298-301

2. World Health Organisation. Latest HIV estimates and updates on HIV policies uptake, July 2020

3. National AIDS Control Organization \& ICMRNational Institute of Medical Statistics (2020). India HIV Estimates 2019: Report
4. Ssentongo P, Heilbrunn ES, Ssentongo AE, Advani S, Chinchilli VM, Nunez JJ, et al. Epidemiology and outcomes of COVID 19 in HIV infected individuals: a systematic review and meta analysis. Nature Scientific Reports 2021; 11:62-83. https://doi.org/10.1038/s41598021-85359-3

5. Yang X, Sun J, Patel RC, Zhang J, Guo S, Zheng Q, et al. Associations between HIV infection and clinical spectrum of COVID-19:a population level analysis based on US National COVID Cohort Collaborative $\left(\mathrm{N}_{3} \mathrm{C}\right)$ data. Lancet HIV 2021;8(11):e69o-e7oo. https://doi.org/10.1016/S2352-3018(21)oo239-3

6. Karthika PS, Rathy R, Jayanthi P, Harish RK, Ameena M, Krishnasree RJ. Oral Manifestations of COVID-19 Patients: A Systematic Review. J Orofac Sci 2021; 13:7381. https://doi.org/10.4103/jofs.jofs_91_21

7. Ramakrishnan $\mathrm{H}$, Ragupathi M. Orofacial manifestations of COVID-19. Oral Health Craniofac Sci. 2021; 6:006-007. https://doi.org/10.29328/journal.johcs.1001034

Cite this article as:

Singh M. An Overview of HIV on World AIDS Day: A Short Commentary. Int Healthc Res J. 2021;5(9)SC1-SC2. https://doi.org/10.26440/IHRJ/0509.12480

\section{AUTHOR AFFILIATION:}

